(c) American Dairy Science Association, 2006.

\title{
Major Advances in Milk Marketing: Government and Industry Consolidation
}

\author{
D. Stukenberg, ${ }^{* 1}$ D. Blayney, $†$ and J. Miller† \\ *USDA, Dairy Programs, Market Administrator's Office, Lenexa, KS 66219 \\ †USDA, Economic Research Service, Washington, DC 20036-5831
}

\begin{abstract}
Federal dairy programs have been instituted to assist dairy farmers in marketing their milk. Milk marketing licenses were issued for city markets in 1933 during the depression. Federal Milk Orders replaced licenses in 1937 with enactment of the Agricultural Marketing Agreement Act. Low prices returned in the late 1940s and Congress passed the Agricultural Act of 1949 creating the support program for milk. Congressional involvement in milk marketing was minimal until passage of the 1977 Farm Bill. A support price adjustment to seek favorable political responses from farmers resulted in higher prices and ultimately higher production. Large expenditures and burdensome supplies caused Congress to make major changes to both programs. Other milk marketing programs have evolved from Congressional actions, including export and promotion programs. The exiting and consolidation of the dairy processors and producers has lead to a reduction in the number of marketing orders.
\end{abstract}

Key words: federal milk market order, support price, Class I differentials, classified pricing

\section{FEDERAL MILK MARKETING ORDERS}

The federal milk order (FMO) program provides dairy producers a means of equally sharing revenues generated by a classified pricing system. Handlers (processors) are assured of paying the same minimum price as their competitors for milk used within the same product classification. Federal milk orders ensure that handlers are accountable for the classified value of the milk they receive, and that producers who supply these handlers are paid equally.

Federal milk orders are instituted at the request of dairy producers usually through cooperative representation. The USDA will hold an administrative hearing to promulgate an order or to issue decisions amending

Received September 16, 2004.

Accepted December 2, 2004.

${ }^{1}$ Corresponding author: david.stukenberg@Fmmacentral.com an existing order if disorderly marketing is thought to exist and product is moved through interstate commerce. Producers supplying handlers within the marketing area must approve the issuance or amendment of an order by a two-thirds margin. An order may be terminated at the request of $50 \%$ of the producers supplying the market. A federal order marketing area is generally defined as the geographical boundary where handlers compete for Class I sales.

Orders only set minimum prices for milk received by processors based upon a classified system. There have been 4 classes of use since January 2000. Class I is the highest priced and consists of fluid milk products including flavored milk and buttermilk (Figure 1). Class II products include cream, cottage cheese, ice cream, and yogurt. The Class II minimum price is currently set at a fixed differential of $\$ 0.70$ per hundredweight (cwt) above the Class IV price. Class III includes all cheeses except cottage cheese, whereas Class IV is applicable to butter and powdered products. Before order reform in 2000, there were 3 classes of use, and butter and powdered products were included in Class III. In some markets, nonfat dry milk powder was designated Class III-A, and priced lower than Class III.

The USDA supports the milk price to dairy producers through purchases of storable dairy products; primarily butter, nonfat dry milk, and cheese (Figure 2). Processors may sell these products to the government at a rate determined by USDA, which enables them to pay producers the targeted support price. Economic forces determine prices when dairy product markets are tight. However, during surplus periods, the government often becomes a market of last resort. In many ways, the support program complements the federal order classified pricing system by setting a price floor for manufactured products.

Before order reform in 2000, prices were determined by surveying the prices paid to manufacturing grade producers in Minnesota and Wisconsin. Although not directly tied to the support price, federal order prices can be closely related to support prices in times of milk and dairy product surpluses. When support prices are artificially high, they inflate market prices and federal order prices capture these higher prices (Figure 3). 


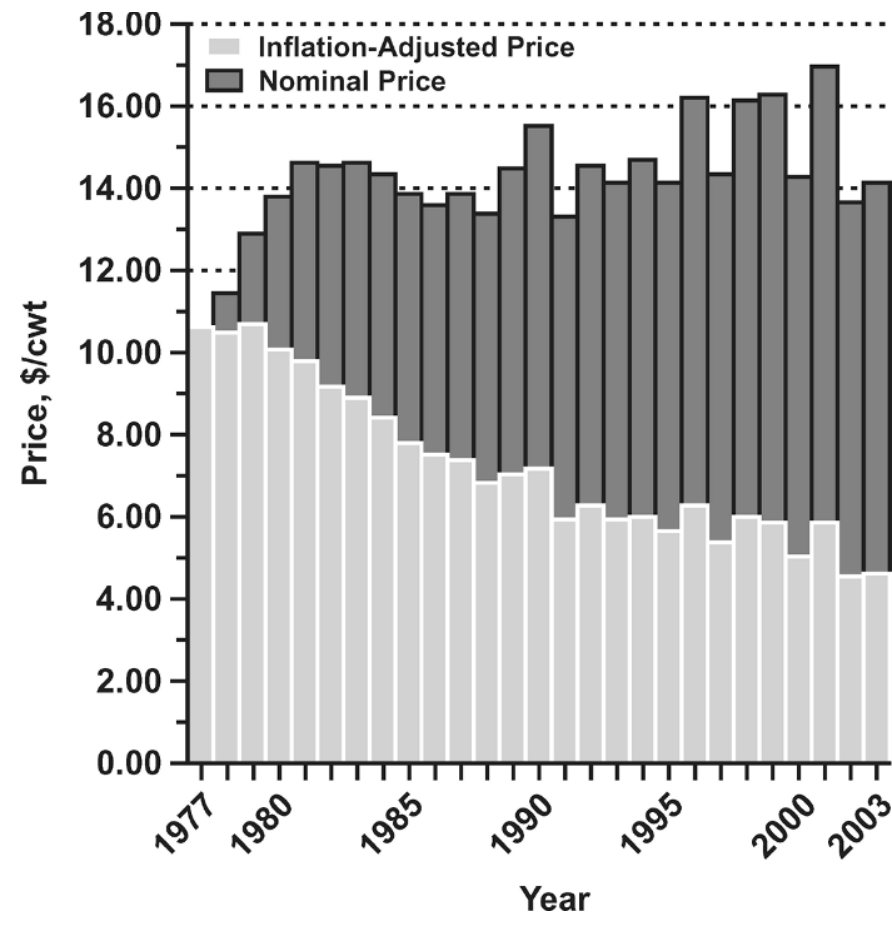

Figure 1. Federal milk marketing order Class I prices (annual averages) from 1977 to 2003.

Congressionally mandated (not farmer-requested) order reform is the single most sweeping change in the FMO program over the past $25 \mathrm{yr}$. The legislative process from which order reform evolved is a story unto itself.

\section{Legislative Involvement}

The Food and Agriculture Act of 1977 (Farm Bill) required that the support price for manufacturing milk be adjusted semiannually to reflect changes in the parity index of prices paid by farmers for commodities and services, interest, taxes, and wage rates. The parity index is published monthly in Agricultural Prices where 1910 to $1914=100$. The semiannual adjustments resulted in a rapid rise in the support price for milk (3.67\% butterfat), moving from $\$ 9.00 /$ cwt in 1977 to $\$ 13.49 /$ cwt for the first $20 \mathrm{~d}$ in October 1981.

Milk price increases resulted in predictable production responses from dairy producers. Milk production in the US totaled 115.4 billion pounds in 1975 and increased at an average annual rate of $2.39 \%$ until 1985 when 143.0 million pounds were produced (Figure 4). Consequently, purchases by the USDA's Commodity Credit Corporation (CCC) escalated during this time in an effort to support the milk prices. Pressure began

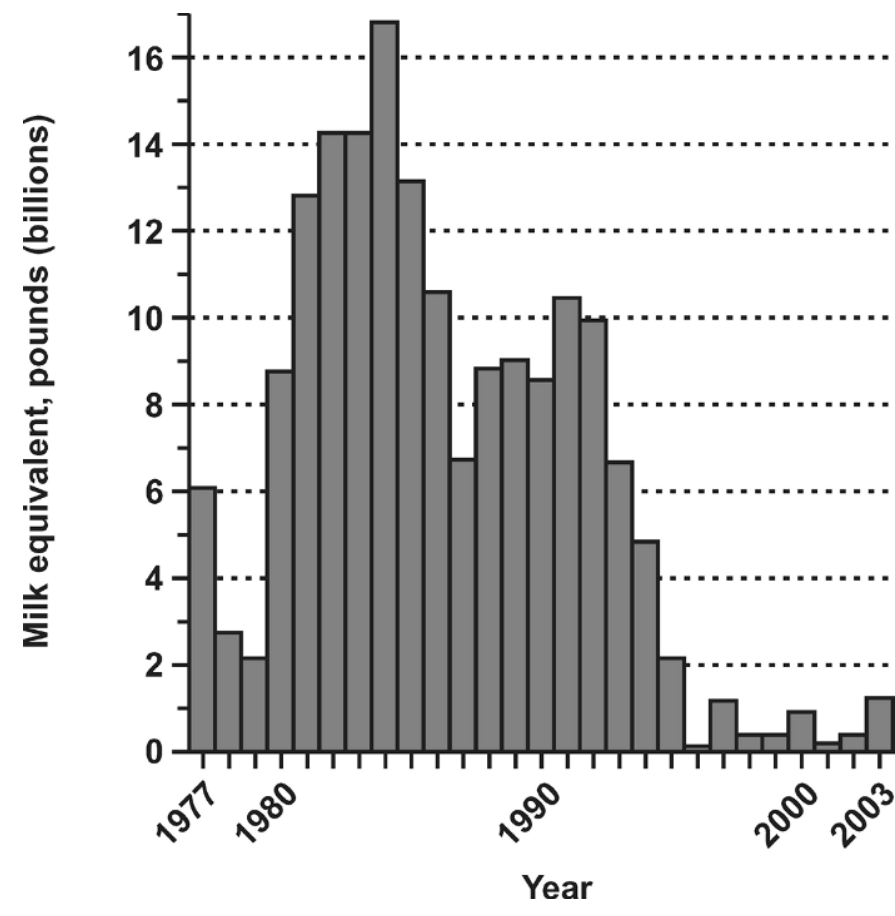

Figure 2. United States Department of Agriculture net removals on milk-equivalent, milkfat basis.

to mount for Congress to restrict the amount of taxpayer dollars being spent on dairy programs.

The 1977 Farm Bill's semiannual adjustment based on the parity index resulted in a record high $\$ 13.49$ / cwt support price by October 1981. President Ronald Reagan signed temporary legislation on October 20, 1981, which rolled back the increase for the 1981 to 1982 marketing year (October-September) to $\$ 13.10 /$ cwt. However, purchases continued to increase. The support price remained at $\$ 13.10 /$ cwt until December 1983. The Omnibus Budget Reconciliation Act of 1983 introduced something new-Assessments. This Act's dairy legislation provided for a $\$ 0.50 / \mathrm{cwt}$ deduction on all producer milk marketed beginning December 1, 1982. These assessments were to offset a portion of the cost of the dairy support program. An additional $\$ 0.50$ assessment was imposed from September 1, 1983 to November 30, 1983 because of expected purchases exceeding 7.5 billion pounds on a milk-equivalent basis. The second assessment was refundable if producers reduced their marketings from the previous year.

Effective with the signing of the Dairy and Tobacco Adjustment Act of 1983 by President Reagan, the support price was decreased $\$ 0.50 /$ cwt on December 1 , 1983. The law retained the first $\$ 0.50$ assessment and provided for a $\$ 0.50$ decrease in the support price on April 1, 1985, if CCC purchases exceeded 6 billion 


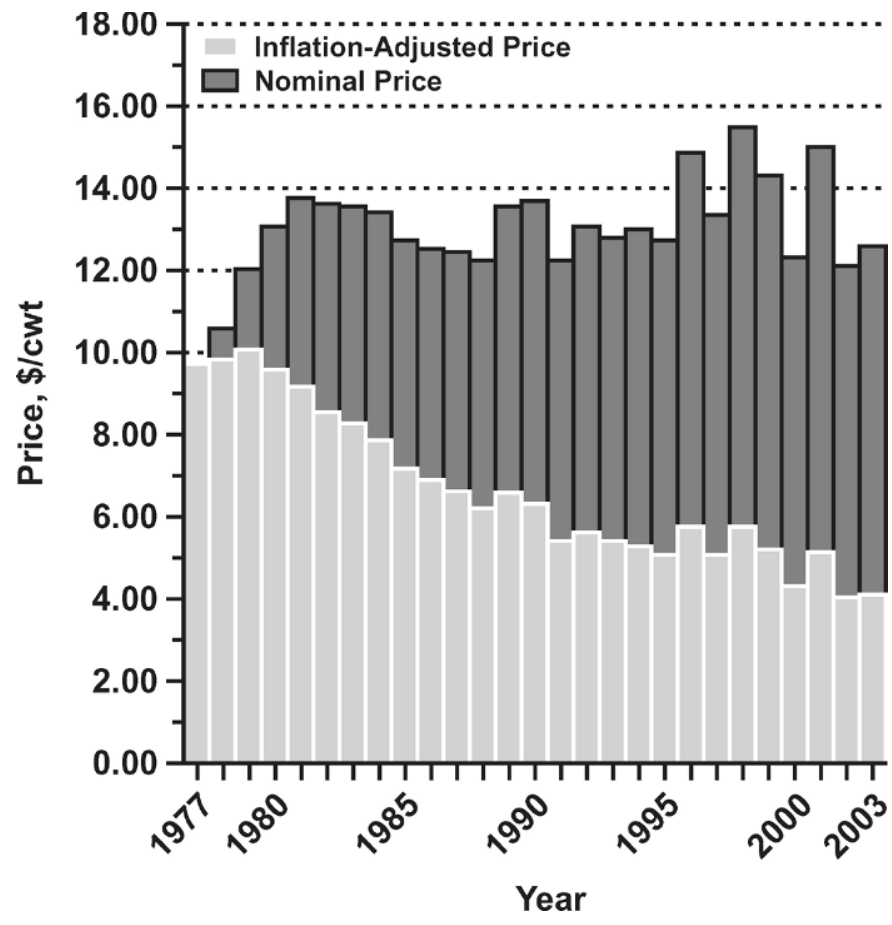

Figure 3. Prices received by farmers for all milk, 1977 to 2003.

pounds milk equivalent in the succeeding $12 \mathrm{mo}$. An additional $\$ 0.50$ decrease was authorized if purchases exceeded 5 billion pounds on July 1, 1985. Both support

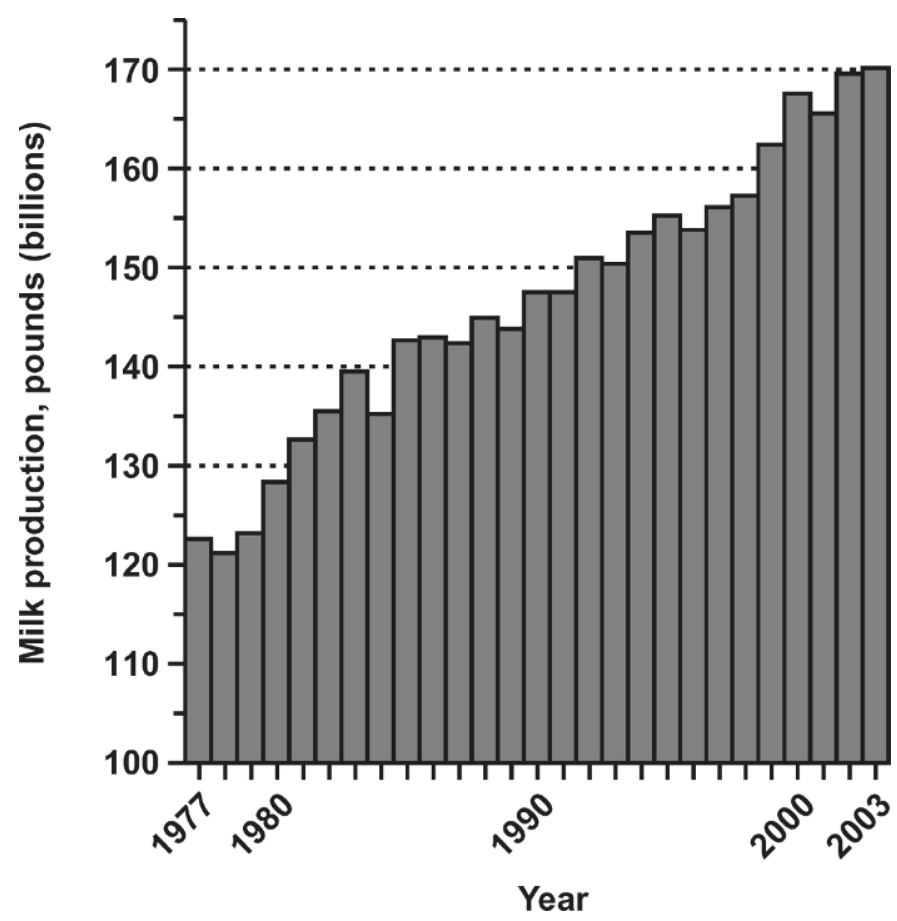

Figure 4. United States annual milk production, 1977 to 2003.

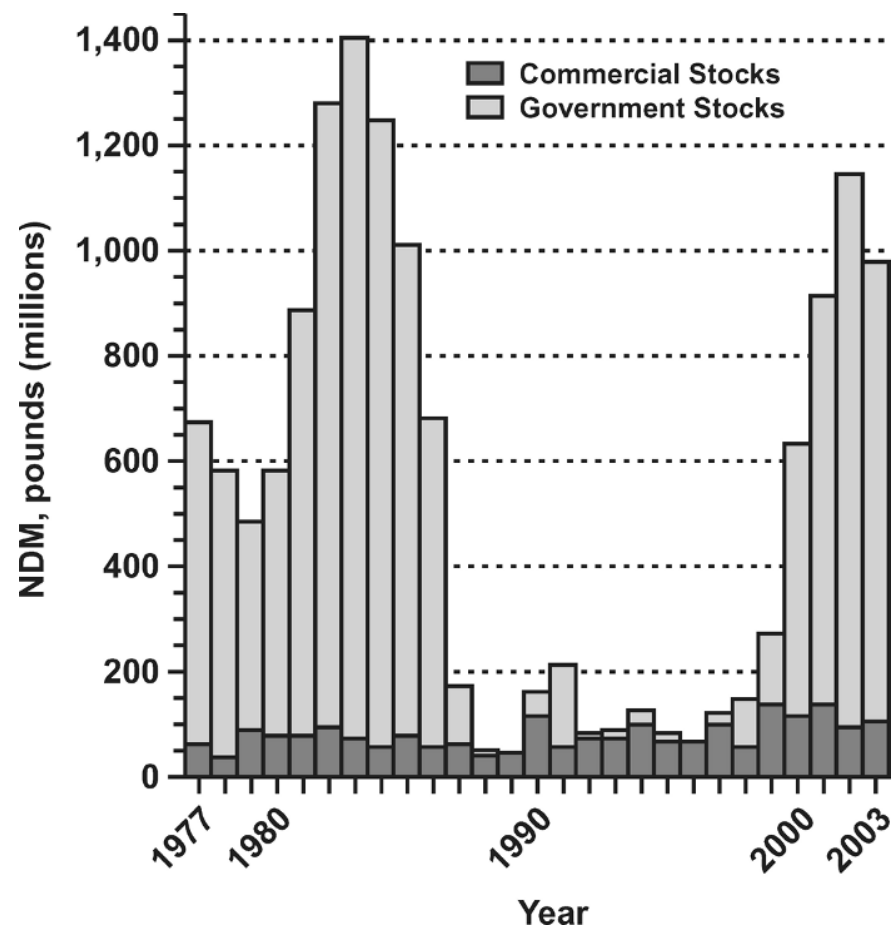

Figure 5. Nonfat dry milk stocks at year-end, 1977 to 2003.

price decreases occurred as scheduled and lowered the support price to $\$ 11.60 / \mathrm{cwt}$.

Congress agreed on the Food Security Act of 1985 (Farm Bill) in the fall of 1985 as the government was burdened with huge inventories of butter, nonfat dry milk, and cheese (Figures 5, 6, and 7). Congress implemented the Dairy Termination Program as a means of encouraging producers to exit dairying. Producers wishing to exit dairying were asked to submit bids based on their production history (usually the previous $12 \mathrm{mo}$ ). The bids for herd disposal or export were accepted in 3 periods so as not to burden cattle markets. The periods were: April-August 1986, September 1986February 1987, and March 1987-August 1987. Producers whose bids were accepted were required to refrain from milk production for $5 \mathrm{yr}$ following disposal of their cattle. All bids up to $\$ 22.50 /$ cwt were accepted. The Dairy Termination Program was funded by a $\$ 0.40 / \mathrm{cwt}$ assessment on all US milk marketings from April 1, 1986 to December 31,1986 , and $\$ 0.25 /$ cwt assessment from January 1, 1987 to September 31, 1987.

The milk support price was periodically decreased over the life of the 1985 Farm Bill, eventually reaching $\$ 10.60 /$ cwt for January 1, 1988 to December 1989. However, it increased to $\$ 11.10$ from April to June 1989 under the Disaster Assistance Act of 1988, prompted by higher feed prices due to drought conditions. 


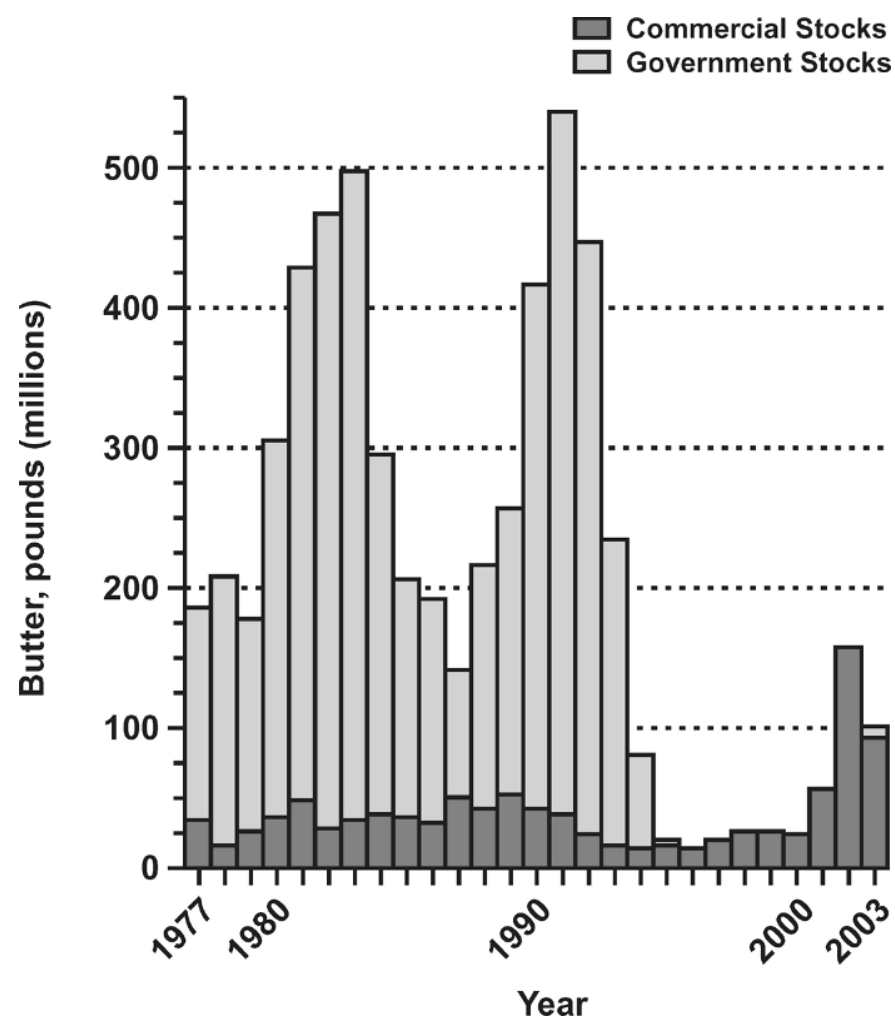

Figure 6. Butter stocks at year-end, 1977 to 2003.

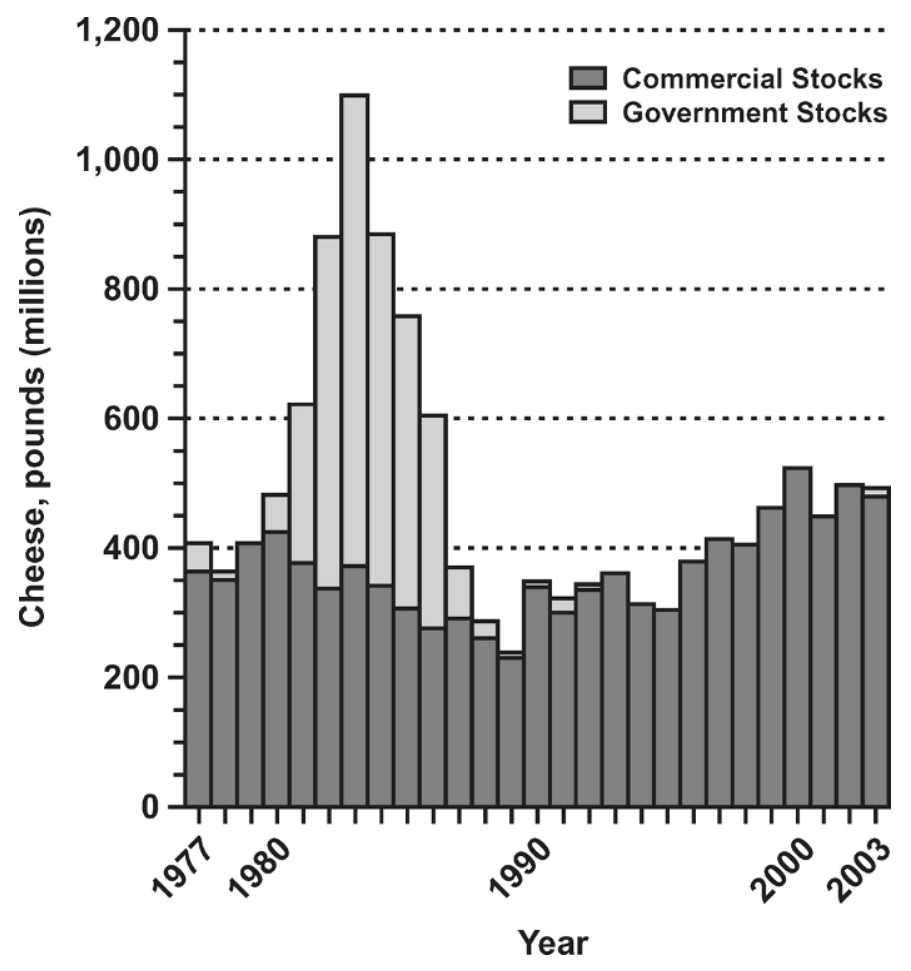

Figure 7. American cheese stocks at year-end, 1977 to 2003.

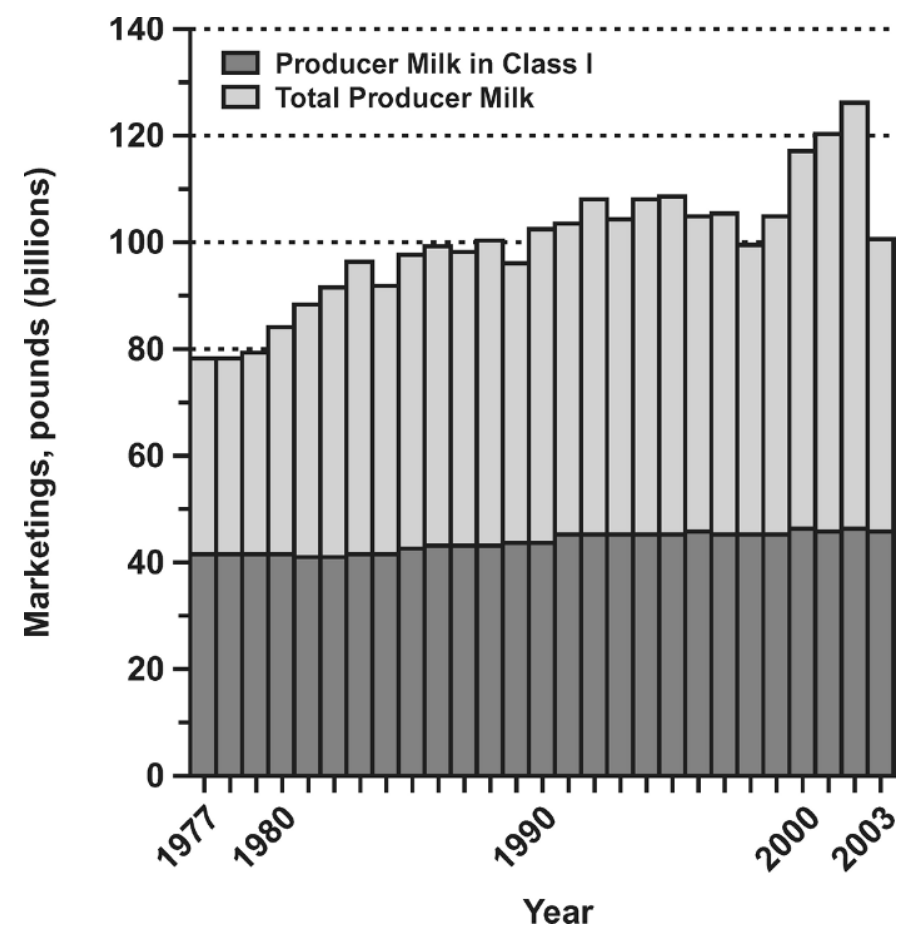

Figure 8. Federal milk order producer marketings, 1977 to 2003.

Dairy surpluses and government expenditures continued to cast a shadow over the support program. The Omnibus Budget Reconciliation Act of 1989 allowed the Secretary of Agriculture to drop the support price to $\$ 10.10 /$ cwt if CCC purchases exceeded 5 billion pounds. This decrease occurred on January 1, 1990.

Dairy programs were recognized as a major expenditure when US budget deficits were reviewed. An additional $\$ 0.12 /$ cwt assessment was placed on milk marketed from April through September 1986 due to the Gramm-Rudman-Hollings Balanced Budget and Emergency Deficit Control Act. This assessment reappeared as a $\$ 0.025$ deduction during all of 1988 , and a $\$ 0.063$ deduction in January 1990. Many producers likened it to a tax on their milk marketings.

The 1985 Farm Bill addressed the issues of increased milk production, the growing stockpile of butter, nonfat dry milk, and cheese, and the resulting increased government dairy expenditures. Lower milk prices and assessments helped balance milk supplies with demand. The producer-funded buyout program slowed increases in milk production (Figure 8). The average annual production increases of $2.28 \%$ from 1981 to 1985 dropped to $0.66 \%$ from 1985 to 1990 .

Overall prices to producers and processors decreased from a 1981 average fluid grade all milk price of $\$ 13.94 /$ cwt to $\$ 12.35 / \mathrm{cwt}$ in 1988 . However, some fluid milk 
processors experienced an increased cost through higher Class I differentials. The 1985 Farm Bill realigned the Class I differentials in 35 of the 44 federal orders in existence at the time. Upward adjustments were made to most of the federal order Class I differentials varying from an $\$ 0.08 / \mathrm{cwt}$ increase in the upper Midwest order to a $\$ 1.03 / \mathrm{cwt}$ increase in the Southeastern Florida order.

Class I differentials serve as a pricing mechanism to partially compensate suppliers for transporting milk to the market from production areas. Factors used in determining Class I differentials include the supply and demand conditions in the market, costs of alternative supplies, and the cost of producing milk in the supply areas including the additional cost of Grade A production. Congress determined that a hauling rate of $\$ 0.015 /$ cwt per 10 miles, previously used to calculate location differentials, was too low and should not be used in the future.

\section{Class I Differential and Regionalism}

New Class I differentials became effective May 1, 1986, and immediately drew objections from many dairy groups. Dissatisfaction with the Class I pricing structure became so severe (especially in the upper Midwest) that the Secretary of Agriculture announced on March 29, 1990, that a national hearing would be held. Seventy proposals relating mostly to pricing and reconstituted milk issues were received from the industry and interested persons. An administrative hearing was held to receive testimony and evidence relative to the proposals. The hearing commenced at Eau Claire, Wisconsin, on September 5, 1990, and concluded in Irving, Texas, on November 20. The hearing lasted $43 \mathrm{~d}$, and other hearing sites included Minnesota, New York, and Florida. Approximately 200 witnesses including dairy farmers, state and federal elected officials, cooperative representatives, plant operators, representatives of dairy organizations, and university economists participated in the hearing. The proceedings produced approximately 10,000 pages of transcripts, 237 exhibits, and an estimated 3,000 pages of officially noticed documents.

Following the hearing, a recommended decision was issued in November 1991, and a final decision in January 1993. Although no changes to the Class I differentials were deemed necessary, a minor change was made to the Class II differential in selected orders. All orders were amended to include a concentrated milk definition and a Class I credit of $\$ 1.00 / \mathrm{cwt}$ was instituted for labeled reconstituted milk rather than the full Class I price on a milk equivalent basis. In effect, more than $2 \mathrm{yr}$ were spent discussing the issues and little changed.
Dissatisfaction with the Class I price surface still existed within the upper Midwest dairy industry whose Class I prices to handlers remained lower than those of handlers in the rest of the country.

The November 1994 general elections proved fruitful for dairy interests in the upper Midwest. Representative Steven Gunderson (R-WI) was reelected to Congress and appointed chairman of the Livestock, Dairy and Poultry subcommittee. The upper Midwest dairy industry gained an important and influential advocate.

Positioning for the 1995 Farm Bill began almost immediately with Congress aligning with regional and partisan dairy interests. Representative Gunderson stated the industry would have to support comprehensive reforms of government programs or he would deregulate the industry. Gunderson proposed creating a single national order with a common minimum manufacturing price, and creating 5 pricing zones for the national pooling of a $\$ 1$ Class I differential tied to use within each zone. He also proposed terminating the price support program and establishing a national Class IV pool, which would return to producers the difference between a target price for milk used to produce butter and nonfat dry milk and the actual market price.

Mid-American Dairymen, Inc. (MidAm), a predecessor cooperative of Dairy Farmers of America, rejected Gunderson's proposed changes to the federal order pricing, and even proposed raising the Class I differentials in any market with more than $40 \%$ Class I use. Representative Gunderson next proposed to end federal order pricing and the support program by July 1, 1996, while retaining the audit and verification features of the FMO program. MidAm countered by withdrawing the Class I differential increases, but Gunderson also rejected this change. Agreement on the dairy provisions had reached stalemate in the House. The Senate initially adopted a version of the Farm Bill that included no changes to federal orders, but reduced the support price for cheese and eliminated support prices for butter and nonfat dry milk.

It became apparent that consensus on many agricultural issues, not just dairy, would be difficult to achieve due to budget cutbacks and reforms. The chances of a Farm Bill in 1995 faded well before the December recess.

Positioning for the presidential primaries began in late 1995. Senate Majority Leader Robert Dole (R-KS) and Senate Agriculture Committee Chairman Richard Lugar (R-IN) were both presidential contenders trying to attract votes in the Northeast. In an effort to gain Senate support, they allowed amendments to the dairy title of the budget bill when it was introduced. Senator Jim Jeffords (R-VT) immediately introduced the New 
England Compact as an amendment. The New England states could individually approve the Compact whereby they could collectively charge processors an agreedupon Class I premium that would increase returns to dairy farmers.

The budget bill then moved to the House-Senate Conference Committee to iron out the differences between the House and Senate versions. Representative Gerald Solomon (R-NY) was determined to keep FMO and threatened that all New York representatives would vote against the budget bill if the Senate version relating to federal orders was altered. Fearful that the dairy title of the budget bill would stall the entire package, Speaker of the House, Newt Gingrich (R-GA), elected not to include dairy in the budget bill. Ironically, the bill was eventually vetoed by President Bill Clinton. Dairy provisions now became part of the "1996" Farm Bill.

Congressman Gunderson tried expanding his efforts to reform dairy price regulation or deregulation by seeking common ground within the industry. The National Milk Producers Federation, an organization of dairy cooperatives, developed a compromise by which they sought to floor the Class I price at January 1996 levels, create national pooling of Class I, and also pool half of the difference between the cheese milk support price and the market price for milk used to produce nonfat dry milk. They also wanted to repeal all assessments, reduce the number of federal orders, and agreed to terminate the support price on butter and nonfat dry milk.

In Congressman Gunderson's effort to secure the approval of California producers who pool under a State order, provisions were made to include California producers in the Class I national pool. Also, California's requirement for a higher milk solids content on packaged fluid milk products would be applied nationally and the support program make allowance on cheese would be adjusted to align more closely with California's make allowance.

The House Livestock, Dairy and Poultry Subcommittee and the House Agriculture Committee agreed upon a new dairy title in February 1996. Immediately, the International Dairy Foods Association, an organization of dairy processors, protested the increased solids standards and the flooring of the Class I price, citing an increased cost to processors and consumers (Figure 9). A media campaign was mounted opposing the dairy title and noting the increased cost and the adulteration of packaged milk. This publicity, and Congressman Solomon's refusal to allow changes to the federal order part of the Bill, made agreement unlikely.

Congressman Solomon joined Congressman Calvin Dooley (D-CA) and introduced an amendment that aligned with the Senate Agricultural Committee's pro-

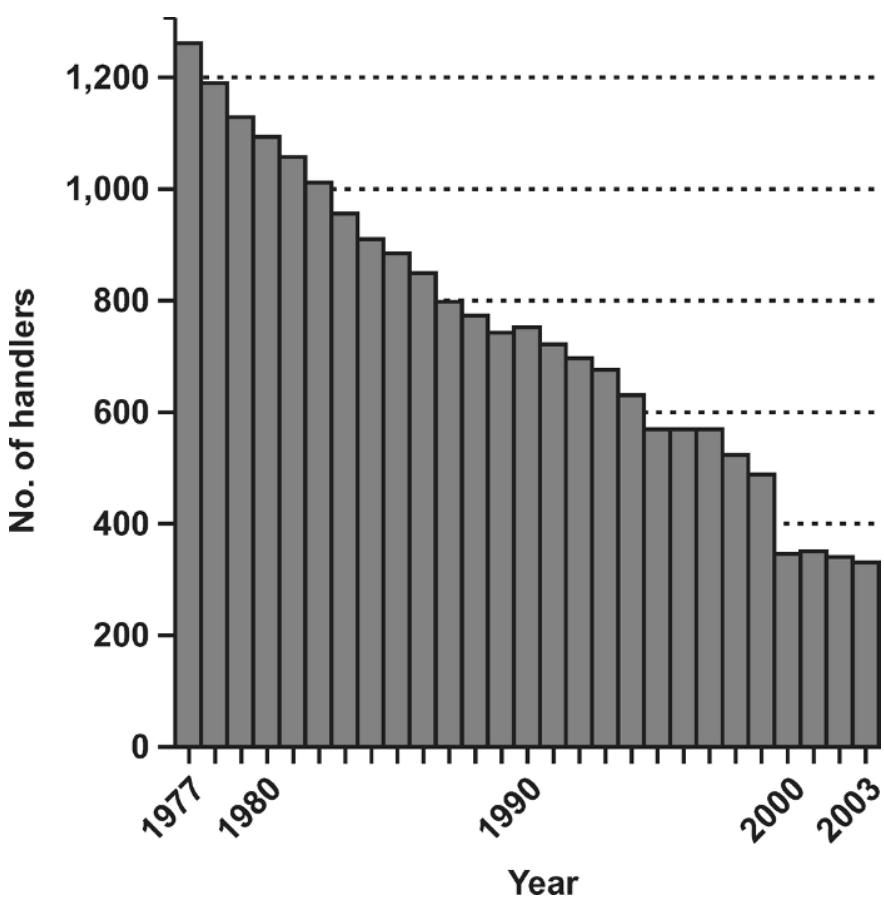

Figure 9. Federal milk order handlers, 1977 to 2003.

posal written by Senator Lugar and his staff. The Senate bill, however, was never submitted to the Conference Committee, thus only the Solomon-Dooley Bill was set for markup. The Conference Committee shortened the time required to consolidate federal orders, set the number of federal orders to be between 10 and 14, and suggested that USDA consider using multiple-base pricing points rather than the single pricing point (Eau Claire, WI). The USDA was instructed to review the Class I differentials by basing them on the fluid use in each order and replace the Minnesota-Wisconsin price series by utilizing multiple component prices for setting the manufactured product prices (Classes II, III, and IV). These prices were also to serve as the base for determining Class I prices. In addition, informal rule making (no administrative hearings and open discussions) was to be allowed in formulating the federal order reforms. The Conference Committee also included the Northeast Compact, much to the dismay of the Midwest constituents. Producer assessments would end and the support price program would be phased out over a 4yr period ending in 1999 and replaced with a recourse loan program.

The Federal Agriculture Improvement and Reform Act of 1996 moved out of Conference Committee in February and was signed by the President Clinton on April 4, 1996. The USDA's Dairy Programs, saddled with an April 4, 1999, deadline to manage all proposed reforms, 
immediately formed committees to address specific issues. The committees included: Price Structure, Basic Formula Price, Identical Provisions, Classification, and Regional. The Regional Committee was divided into 4 subcommittees. Committee membership included both Dairy Programs field and headquarters staff.

\section{The Federal Order Reform Process}

Partnerships were established with Andrew Novakovic, Cornell University, and Ronald Knutson, Texas A\&M University, to provide analysis on price structure and the basic formula price options. Novakovic published a staff paper and a research bulletin on dairy prices as they related to the structure of the industry. Two working papers by Knutson examined the alternative pricing mechanisms to the basic formula price and product prices relative to raw milk values. Both papers were used in developing the Class I price surface and in the analysis of milk price discovery options.

A public forum was held in Madison, Wisconsin, in July 1996, to solicit concepts and proposals for using manufactured product prices to replace the Basic Formula Price. Thirty-one participants including Senators, Congressmen, university professors, dairy farmers, cooperative representatives, and processors made presentations at the forum.

In the following months, several memoranda and reports dealing with order provisions, consolidation, and pricing issues were released to the industry. The response from the forum and releases was overwhelming. The USDA received more than 1,600 individual comments and an additional 3,000 form letters. Dairy Programs personnel continually met with interested parties throughout the order reform process. They addressed more than 250 groups comprising more than 22,000 individuals on the reform issues. Seven briefing sessions for congressional members and committees were held to keep them abreast of the issues and progress with the Farm Bill mandates. A recommended decision was issued on January 21, 1998.

The decision would consolidate the current 31 FMO into 11 orders (Figure 10) and create a new and separate Class IV to include milk used to produce butter and powdered products. Cheese would remain in Class III. A multiple component pricing system derived from product prices would replace the Basic Formula Price. Market prices based on National Agricultural Statistical Service surveys for cheese, butter, nonfat dry milk, and whey transactions would be used to calculate the component prices for butterfat, protein, and other solids contained in producer milk and for milk used by processors. Class I prices would continue to be announced in advance, but with a shorter lead time of 7 to $13 \mathrm{~d}$,

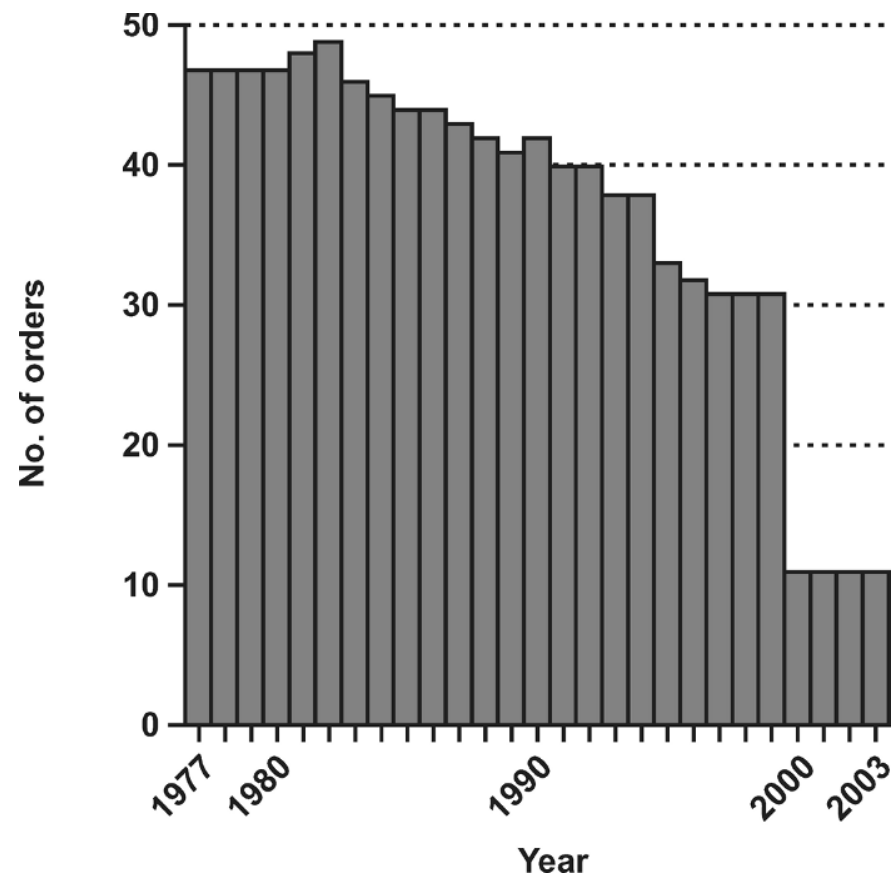

Figure 10. Federal milk marketing orders, 1977 to 2003.

compared with the then current $55 \mathrm{~d}$, in an attempt to address the problem of price inversions between Class I and manufacturing classes. The Class I price would also be based on the higher of an advanced Class III or Class IV price plus the Class I differential.

The Class I price structure was still the most contentious issue under reform, just as it had been since the 1986 Farm Bill. The USDA included 2 Class I proposals in the decision, which used the studies and data provided by Cornell University. Option 1A stipulated location-specific differentials similar to those currently being used. Option 1B was identified as Relative ValueSpecific Differentials. Option 1B flattened the price surface considerably and was deemed to be market-oriented in that cooperatives and bargaining associations would be expected to increase their efforts to negotiate higher over-order prices from their customers; the USDA supported Option 1B.

Congress extended the time for implementation of reform in October 1998. They specified that the final decision must be issued by April 4, 1999, and implemented by October 1, 1999. Provisions were also made for California to become a federal order by September 30,1999 , if they so desired.

\section{Regionalism Still a Factor}

The final decision was published in the Federal Register on April 2, 1999. Changes from the recommended 
decision were mostly a "fine tuning" of the provisions based on comments received. However, the Class I pricing structure issue consisted of a modified Option 1B Relative Value-Specific Differentials. The Class I price surface was flattened, but not to the extent originally proposed. The Class I differential at Minneapolis, MN, was increased $\$ 0.40$. Further south in Dallas, TX, it decreased by $\$ 1.06$, in Phoenix, AZ, it decreased $\$ 0.97$, and in Atlanta, GA, it decreased $\$ 0.18$. The overall average was $\$ 0.29$ lower than differentials in use before reform. Regionalism was still alive.

Federal order reform was approved by a producer referendum and scheduled to take effect October 1 , 1999. However, an injunction was issued by the US District Court in Vermont preventing its implementation until further notice. Congress then passed the Consolidated Appropriations Act 2000 on November 29, 1999 , requiring USDA to revise the final rule by adopting the Option 1A location specific differentials contained in the recommended decision. Federal order reform became effective January 1, 2000.

Effectively, federal order reform increased Class I differentials in the upper Midwest, and lowered them in certain areas in the Southwest and West where supply exceeded demand. Product price formulas are now used in determining class and component prices replacing, the basic formula milk price survey. Seven of the federal orders included provisions for paying producers based on multiple components-butterfat, protein, and other solids. Four of these component orders also provided for somatic cell adjustments to producer milk prices. The other 4 orders continued to pay producers on a skim milk and butterfat basis. A Class IV was created for milk used in butter and powdered products. The number of FMO was reduced from 31 to 11 . This likely was inevitable as processor distribution of product continues to expand into larger regional patterns.

Pricing issues still were not settled. Congress stipulated a review of the Class III and Class IV pricing formulas in the Appropriations Act. A national hearing was held in May 2000 to receive evidence on the pricing formulas. Most testimony centered on adjustments to make allowances and yield factors used to convert product prices to component and class prices. The final decision issued December 2000 reduced the cheese make allowance and eliminated the butterfat adjustment portion in the protein price formula, and it increased the make allowances used in the Class IV component price calculations. Separate Class III and Class IV butterfat values were also established. The amendment was to be effective January 1, 2001, but an injunction was issued by the US District Court for the District of Columbia on January 31, 2001. The court enjoined the use of separate butterfat prices for Class III and Class
IV and stipulated make allowances and yield factors. The USDA was required to again review the hearing record. A decision was issued and revised pricing formulas became effective April 1, 2003.

Other FMO issues have been (and will continue to be) addressed since the January 1, 2000 reform. These include the pooling of producer milk on 2 market-wide pools (federal and state) and pooling distant milk without regularly delivering milk to handlers on the order while financially benefiting from the pool. The termination of the Western order in April 2004 was the result of one producer group no longer being willing to share Class I proceeds with producer groups in surplus areas. Additional concerns for the order program are the right to depool producer milk when prices are not favorable, inverse price relationships where the Class I price is not the highest class price, and defining and/or classifying products containing milk fractions. Make allowances and possibly yield factors will likely need revisions in the future as energy costs fluctuate and production technology evolves.

Solutions to these and future problems will be solved through industry participation in the order program. The dairy industry's needs and innovations have been accommodated under the FMO program since its enabling legislation-the Agricultural Marketing Agreement Act of 1937. Congressional intervention in dairy marketing issues has been unprecedented over the last $25 \mathrm{yr}$. Federal order reform, with the issues and events leading up to its enactment, has been a story unto itself.

\section{CONCENTRATION AND GLOBALIZATION}

Concentration in milk and dairy product processing and manufacturing is linked directly to the process of structural change in the dairy industry. At a minimum, questions about structure focus on the number and size of firms. Firm location, business organization and strategies, and market shares are also important. Linkages among or between firms, including the ongoing globalization of the industry are also key factors to consider. The changing structure of the US dairy industry over time can be attributed to a variety of factors.

Technological advances in milk assembly, storage, processing, manufacturing, packaging, and marketing underpin concentration of the dairy processing and manufacturing industries by promoting in-plant economies of size. There has been increasing concentration on both sides of the industries, by farms (milk suppliers) and by product buyers (whether retail chains, restaurant chains, or food processors), that has prompted growth so that customers can be efficiently served. Coordination between or among firms, and within them, 


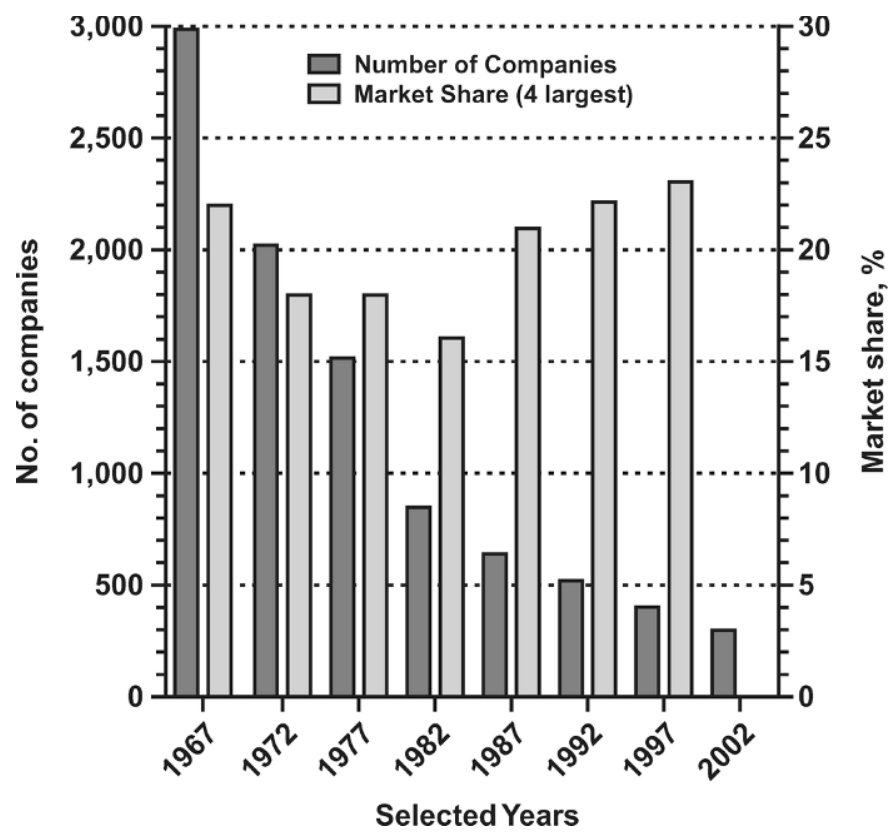

Figure 11. Number of fluid milk companies, and market share of the 4 largest companies in selected years from 1967 to 2002.

has improved in an age of almost instantaneous communication. Evolving business organizations and strategic strategies for operating in the dairy product markets have also played a key role. All of the factors have helped place economic decision-making in fewer and fewer individuals.

From 1963 to 1997 (the last Census of Manufactures for which complete information is available), the number of companies comprising various dairy product businesses has declined in almost all cases, and by significant numbers (Figure 11). Only for dry, condensed, and evaporated milk has the number not fallen; it actually rose $1 \%$. Fluid milk and butter company numbers have declined by $90 \%$ or more. The decrease for cheese, ice cream, and frozen dessert firms is in the 55 to $60 \%$ range. It is not likely that such dramatic changes in firm numbers will be seen in the future but there is room for further downward adjustment in the businesses.

The dramatic decline in firms producing the various milk and dairy products is not mirrored by a drastic change in firm concentration, except for butter. Using the 4-firm share of total shipments as a measure, concentration in butter jumped from 11 to $52 \%$. For the other products, the picture is mixed. Concentration actually declined for cheese, ice cream, frozen desserts, and fluid milk, and was up about $18 \%$ for dry, condensed, and evaporated milk.

It was noted that globalization of the US dairy industry was a factor in the issue of concentration. Globaliza- tion is not a monolithic concept, nor is it a particularly new phenomenon. Over time, as barriers to international business relationships have decreased, the differences between operations and strategies of US and foreign-based dairy companies have become fewer. The US dairy market has been unique in that it has offered opportunities for foreign-based firms to both succeed and fail. In essence, US dairy industry concentration issues have taken on a global character.

Major foreign and multinational dairy companies have had most success in US manufactured dairy product markets, especially frozen products (mainly ice cream), cultured products (yogurts), and cheese. Foreign and multinational firms have also moved into the US markets for dairy-based ingredients such as milk protein concentrates and other similar products.

Before 1975, only 2 foreign-based firms, Nestlé (Swiss) and Unilever (Anglo-Dutch), had a significant presence in several US dairy product markets. Over time they have narrowed their focus to one product, ice cream. Since then, several other firms have entered (and exited) US dairy product markets, including Group Danone, Lactalis, and Sodiaal (France), Saputo and Labatt (Canada), Bols Wessanen (Netherlands), Fonterra (New Zealand), and Parmalat (Italy).

Bols Wessanen pulled out of the packaged fluid milk products, ice cream, and cheese businesses worldwide, Sodiaal sold off its US butter interests, and Labatt gave up interests in the US fluid milk business. Parmalat is addressing severe financial problems that likely will result in the sale of US assets. Clearly, globalization does not remove inherent risks associated with marketing milk and dairy products.

Historically, opportunities for joint venture relationships and product supply contracts allowed for international business relationships to emerge, usually among relatively autonomous firms or groups. The general easing of barriers to cross-border associations over time and the convergence of US and non-US firm business goals and strategies has resulted in an environment that promotes relationships that might have been improbable a few years ago. A case in point focuses on Fonterra, a New Zealand dairy cooperative formed in 2001 with 35 manufacturing sites outside New Zealand. The company has forged important relationships with US dairy firms. An initiative with Dairy America, a federation of US dairy cooperatives, makes Fonterra the largest exporter of skim milk powder out of the United States. An agreement with the largest dairy producer-owned cooperative in the US, Dairy Farmers of America, has positioned the company as the largest commercial manufacturer of milk protein concentrate in the country. 
The stories recounted above are one indication of globalization of the US dairy industry. An empirical indicator is foreign direct investment (FDI), the investment in US affiliates by foreign corporations or multinational companies. These parent firms hold a substantial, but not necessarily majority, ownership interest in the affiliates. Direct investments have not been oneway, but US investment overseas is not large.

In 2002, FDI into the United States dairy industry (historical-cost basis) amounted to about $\$ 2.1$ billion, up from 1999 by 78\%. United States investment abroad was $\$ 691$ million, up from $\$ 380$ million in 1999 . Products sold by US affiliates of foreign companies almost exclusively remain in the US domestic markets. Estimated sales by large foreign-owned proprietary firms of about $\$ 10.4$ billion in 2002 represent about $19 \%$ of the sales of all large dairy companies in the US. The share is more than double the share estimated for 1985 $(9.2 \%)$. The US dairy market continues to be an attractive target for investments by non-US firms. It is an open question whether US dairy firms will make any significant changes in how they view overseas markets.

\section{International Markets and the US Dairy Industry}

International dairy markets remain small and heavily distorted by government intervention. However, these markets are considerably less policy-encumbered than they were in 1980, the result of dairy growth in less regulated countries, trade reforms, and the opening of the former Communist bloc. As a result of these changes, international market conditions have gone from being only rarely significant to US domestic markets to being recurrently important.

International prices of dairy products have trended higher since the Uruguay Round Agreement on Agriculture (URAA) created the World Trade Organization (WTO) in 1994, and reforms began to be implemented in 1995. The more important effect of the URAA reforms has been the avoidance of periods of extremely low international prices, a chronic danger in earlier periods. Countries can no longer force international markets to bear the brunt of domestic support miscalculations.

\section{International Market Growth}

Import demand has grown, even though most heavy consuming countries still have barriers to imports. Economic growth and westernization of the diet in many Asian countries have substantially boosted demand. Dry milk demand increased most but demand for milkfat and cheese has also increased. Economic growth in Latin America has been somewhat erratic but has sparked growth in import demand for dry milks and cheese.
Dairy beverages for child feeding remains an important and politically sensitive issue in many countries that traditionally were not significant milk producers. China has embarked on an ambitious program to develop a dairy industry, with uncertain prospects for the ultimate balance between production and use. The higher international prices for dry milk in recent years reduced use in many of the poorer countries as they shifted, in whole or part, to whey products for child feeding.

Milk production has grown rapidly in the major nonsubsidizing exporters. Since 1980, milk output has about doubled in New Zealand and Australia, with the most rapid expansion since 1990. Argentina's growth was slower and more uneven, increasing about half. These Southern hemisphere producers remain firmly pasture-based and have grown by attracting resources away from other pastoral enterprises. Higher international prices since the implementation of the URAA definitely have been an important force.

The dissolution of the former Soviet Union and its bloc has not greatly affected international markets, although the potential ultimate impact is large. Imports and exports in these countries are no longer government controlled, although government policies remained highly influential in some cases. In general, milk production fell after market reforms, as inefficient producers failed. However, consumption also fell as consumer subsidies were removed and incomes dropped. Another chapter was written in 2004 with the absorption of 8 countries into the European Union, with 2 more countries scheduled to be added in 2007 .

\section{WTO and Trade Reform}

The URAA resulted in some increases in import access in most countries. However, the most important change in import policies was the conversion of nontariff barriers to tariff-rate quotas (TRQ). A TRQ allows up to a specified amount to enter at a low tariff. Any additional imports must pay a much higher tariff. Both the TRQ quantities and the "high-tier" tariffs were set in the Uruguay Round negotiations, with the expectation that quantities would be expanded and tariffs lowered in future negotiations. For the United States, the agreement meant that the former absolute quotas under Section 22 were replaced with the negotiated TRQ.

Under the TRQ, an extraordinary gap between international and domestic prices will allow product to enter-even if such imports are far from profitable under normal prices. Such imports of butter and cheese into the United States have occurred on a number of occasions in recent years, reflecting volatile domestic prices and the US's relatively small high-tier tariffs. These 
imports have served as a safety valve of sorts when domestic markets became overheated. Even so, hightier imports were not as large as might be expected on the basis of apparent profitability. The need for rapid shipment and the inherent risk of such imports have limited their amounts.

The URAA placed limits on the amount of a dairy product that can be exported with the use of subsidies and a separate limit on the total expenditures on a product's export subsidies. The limits were based on a specified reduction in export subsidy use from the late 1980s. Because the European Union and Canada both subsidized heavily during the base period, the export disciplines did not result in much actual reduction in subsidized products in most years. They do prevent a return to the extreme quantities of the late 1980s, thereby forestalling recurrent periods of very low international prices.

\section{Impact of Trade Changes on the US Industry}

Under the current WTO regime and expected international market conditions, the US dairy industry is likely to continue to be significantly affected by international markets on a recurrent basis. Substantial commercial exports of nonfat dry milk and butter are expected to occasionally boost US prices, when a period of international price strength coincides with low domestic prices. Large exports of dry whole milk or butter and nonfat dry milk simultaneously are much less probable. Since 1989, there have been $6 \mathrm{yr}$ with significant commercial exports of powder or butter. The smaller price gaps between domestic and international prices also have aided commercial cheese exports. Although the United States is not likely to become fully price-competitive in cheese, it has managed to develop significant niche markets.

Volatility in domestic prices seems destined to continue. If so, high prices probably will make high-tier imports occasionally profitable. The amount of hightier imports will probably expand as exporters learn to position product for quick entry to the United States and make standing arrangements with US users. Hightier imports may well become more effective at dampening price spikes than they have been in the past.

Other than URAA, most of the trade agreements involving the United States (such as North American Free Trade Agreement, Central American Free Trade Agreement, and United States-Australia) have largely excluded dairy products. Incompatible dairy policies were the primary reason for not including dairy products anywhere substantial trade could possibly develop. Dairy trade may play a more prominent role in future agreements, whether they are limited in geographic scope or general under the WTO.

\section{CONCLUSIONS}

The Federal government's role in milk marketing has evolved from indirectly assisting producers through the price support program, to a more direct involvement, sometimes utilizing innovative programs of limited duration. Assessments on producer milk marketings served to reduce government expenditures but did little to reduce production. The whole-herd buyout reduced production but eventually increased prices.

Federal order reform reduced the number of orders, recognizing that, because of advances in packaging technology and improved distribution, processors competed for sales over larger areas. Also, because more producer milk is being processed into cheese than is sold as fluid product, more producers are paid based on the milk components they market. Federal orders have also accommodated the consolidation within the industry for both producers and processors. Regardless of size, producers share equally in the pool proceeds. Local, regional, and national processors are also assured that the minimum price they are required to pay is not being undercut.

Government programs also assist with milk marketing through export enhancement, low income feeding programs, dairy research and advertising and promotion. Trade agreements have created markets for US dairy products and have opened the door to foreign competition. Regardless of government involvement with international dairy trade, the amount of milk product traded remains relatively small compared with the domestic market.

\section{REFERENCES}

Conference Report 99-447. 1985. Food Security Act of 1985. 99th Congress, 1st Session, December 17, 1985.

Conference Report 101-569. 1990. Part 1, Food and Agricultural Resources Act of 1990. 101st Congress, 2nd Session, July 3, 1990.

Conference Report 103-213. 1993. Omnibus Budget Reconciliation Act of 1993. 103rd Congress, 1st Session, August 4, 1993.

Jesse, E. V., and R. A. Cropp. 1996. The Federal Agriculture Improvement and Reform Act of 1996. Paper No. 55, April 1996. Univ. Wisconsin Extension, Madison.

Knutson, R. D., BFP University Study Committee. 1996. An economic evaluation of Basic Formula Price (BFP) Alternatives, AFPC Working Paper 1996-5, Oct. 1996. Online. Available: http:// www.afpc.tamu.edu Accessed Jan. 27, 2006.

Knutson, R. D., D. A. Anderson, and T. Awokuse. Evaluation of "final" four basic formula price options, AFPC Working Paper 1997-9, August 1997. Online. Available: http://www.afpc.tamu.edu Accessed Jan. 27, 2006.

Novakovic, A. 1996. U.S. Dairy sector simulator: A spatially disaggregated model of the U.S. dairy industry. Cornell Univ., Ithaca, NY. No. 96-06, November 1996. Online. Available: http:// cpdmp.cornell.edu Accessed Jan. 27, 2006. 
Novakovic, A. 1997. An economic and mathematical description of the U.S. dairy sector simulator. Cornell Univ., Ithaca, NY. RB9709, Jul. 1997. Online. Available: http://cpdmp.cornell.edu Accessed Jan. 27, 2006.

Proposed Rule. 1998. Federal Order Reform Recommended Decision. Fed. Regist. 63, no. 20, Jan. 30, 1998.

Proposed Rule. 1999. Federal Order Reform Final Decision. Fed. Regist. 64, no. 63, Apr. 2, 1999.

Proposed Rule. 2001. Class III and Class IV Pricing Formulas Decision. Fed. Regist. 66, no. 207, Oct. 25, 2001.
Proposed Rule. 2002. Class III and Class IV Revised Pricing Formulas Decision. Fed. Regist. 67, no. 216, Nov. 7, 2002.

Proposed Rule. 1986. Raising Class I Differentials in 35 of 44 Orders. Fed. Regist. 51, no. 57, Mar 24, 1986.

Proposed Rule. 1991. Concentrated Milk Defined and No Change to Class I Differentials Decision from National Hearing. Fed. Regist. 56, no. 227, Nov 22, 1991.

Public Law 101-624. 1990. Food, Agriculture, Conservation, and Trade Act of 1990. 101st Congress, 2nd session, November 28, 1990. 